\title{
Evaluation of Short-Term Relationships between Selected Investment Funds and the Capital Market in Poland
}

\author{
Aleksandra Matuszewska-Janica', \\ Dorota Żebrowska-Suchodolska $^{1}$, Grzegorz Mentel $^{2}$ \\ ${ }^{1}$ Department of Econometrics and Statistics \\ Faculty of Applied Informatics and Mathematics \\ Warsaw University of Life Science - SGGW \\ Nowoursynowska 166 St., 02-787 Warsaw \\ e-mails: aleksandra_matuszewska@sggw.pl; \\ dorota_zebrowska_suchodolska@sggw.pl \\ ${ }^{2}$ Department of Quantitative Methods \\ Faculty of Management \\ Rzeszow University of Technology \\ Powstancow Warszawy 12 St., 35-959 Rzeszow \\ e-mail: gmentel@prz.edu.pl
}

\begin{abstract}
Investment funds (FIO) as collective investment institutions, place their funds in the stock exchange, thus, participate in financing enterprises. It is true that this share is at the level of several percentage points, but asset transfers at this level can significantly affect the valuation of assets. On the other hand, through the valuation of assets, the stock exchange may also affect the value of participation units of the funds investing in shares. Therefore, the relationship between investment funds and the stock exchange becomes bidirectional. The main aim of the analysis herein is to examine the interaction between the valuation of participation units of selected FIO and the capital market. The analysis includes the share funds existing since 2003. The reference point is the Warsaw Stock Exchange (four main indices: WIG, WIG20, mWIG40 and sWIG80), where these funds invest their cash. The presented analysis is carried out in two stages. The first, an assessment of the interaction between changes in the valuation of fund units and changes in the quotations of the four main WSE indices in Warsaw: WIG, WIG20, mWIG40 and sWIG80. The Granger causality test is used for this purpose. In the second stage, the funds were classified, considering the results of the causality test and portfolio structure. For the clustering, we applied k-means methods. The obtained results indicate two main findings. First, the vast majority of funds, in relation to WIG (whole market index) and WIG20 (bluechip index) are characterized by causality, which can be described as bilateral (Index $\leftrightarrow F I O$ ). In turn, the FIO relationship with the mWIG4O (medium companies index) and sWIG80 (small companies index) can be described as one-sided (Index $\rightarrow F I O$ ). Such a situation is undoubtedly the outcome of the fact that the blue-chip equities have a
\end{abstract}


significant share in the funds' portfolios. Second, the results of cluster analysis point, were that obtained clusters of funds are more diversified because of the structure of the portfolios than the interactions with the main stock exchange indices.

Keywords: open-end mutual funds; stock exchange; short-term relationships; Granger causality

\section{Introduction}

Investment funds, as collective investment institutions, placing their funds on the stock exchange, thus participate in financing enterprises. It is true that this share is at the level of several percent, but asset transfers at this level significantly affect the valuation of assets. On the other hand, through the valuation of assets, the stock exchange may also affect the value of participation units of funds investing in shares. Therefore, the relationship between investment funds and the stock exchange becomes reciprocal.

The purpose of the conducted analysis was, therefore, to check the interaction between the valuation of participation units of selected FIO and the capital market. The analysis includes the Share Funds existing since 2003. The reference point is the Warsaw Stock Exchange, where these Funds invest.

The influence of the behavior of the stock exchange on the valuation of joint-stock units of investment funds is undisputed. As mentioned earlier, the funds invest their funds mainly on the Polish stock exchange, therefore the valuation of the fund units is strictly dependent on the quotations of the assets included in the portfolio. The analyzed funds invest primarily in assets that are taken into account in the construction of major indices (WIG20, mWIG40 and sWIG80). This leads to changes in the indices expressed in changes in indices that will affect the price of participation units.

The relationships between the valuation of FIOs and index quotes are complex. As mentioned earlier, it is not one-way. The influence of the valuation of units on the quotation of indices can be explained in several ways. In a synthetic way, it was taken by [4]. She points out that the influence of funds on the stock exchange can be explained on the basis of such phenomena as: immediate impact, institutional herding or long-term trends. Investment funds have an immediate impact on the price of shares due to the ability to sell significant blocks of shares. Such dependencies were examined, among others [34, 41] or [19]. Institutional herding takes place when one fund buys some value, it is very likely that they will imitate it. This phenomenon was examined, among others [25, 43] or [14]. Investment funds affect stock prices in the long term due to the use of a passive strategy or a gradual increase in their assets. He even mentions a report by the Deutsche Bundesbank [8]. 


\section{Review of the Literature}

Relations between financial time series (to which undoubtedly belong both indexes and series with the valuation of investment fund units) are considered in the field of both short-term and long-term changes. A review of analyzes related to relations for capital markets was presented, inter alia, in the works of: [3] [24].

Long-term relations are largely analyzed in relation to the concept of cointegration $[17,11,12]$. This type of analysis has been widely used since the early nineties of the last century, and its importance has been emphasized, among others, at work [22]. A review of literature in this field is presented, for example, in the works of: [13] and [39]. The concept of cointegration in the analysis of the relationship between "funds" and the capital market was used, among others, in works: [1, 5, $18,35]$ or [2].

As a complement to the cointegration analysis, the short-term compounds are tested using the Granger causality test. One of the possibilities is to run this test based on the Vector Error Correction Model (VECM) [21]. The existence of such relations between the "funds" and the local stock market was demonstrated, inter alia, in the works [35] or [1]. Short-term dependencies are also analyzed using fixed-line financial series, such rates of return or in terms of volatility [26]. Testing causality between the returns on exchange indices and aggregate mutual funds flow is presented, among others, in the works [44] for monthly data and exchanges in Hong Kong and Singapore, [17] quarterly data and the Portuguese exchange and [20] for quarterly data and the S\&P500 index. In turn, analysis for data daily was presented in the paper [33], where the authors showed a relation between the funds flow and the Indian exchange. The study of relationships in the field of variability is presented in the paper [6].

The relationship between the inflow of capital to investment funds and the rates of return from the market has been explained in the literature, among others using feedback trading hypothesis. Investors invest their financial surpluses in funds when stock prices rise, which delays the rise in asset prices. Research for the US market was conducted, among others [42] (using monthly data from 1984-1993) or [37]. Using a similar methodology, they did not observe return relationships between the flows of investment funds and share prices. Completely different results were obtained by [36] [9], who used the monthly rate of return of funds to test the Granger causality test. Dependencies for other markets were indicated by [1] (for the Greek market) or [34] (for the Korean market).

In Polish literature, there are few papers describing the relationship between the value of fund assets and changes in stock market indices. The analysis of the dynamics of the value of assets can be found in Satoły's work [38]. It focuses on the period from June 2006 to March 2010 analyzing capital flows both at the end of the month and in the quarter. Satoła concludes that the development of the investment funds market is one of the factors of the development of the financial market. The upturn in the stock market attracts capital to investment funds, and 
this has a positive impact on the development of the entire market. The rise in the value of assets in 2007 according to Satoła was influenced by both the bull market and psychological factors. The decisions made at that time were a reaction to changes in stock market indices.

\section{Investment Fund Markets in Poland}

The first open-end investment fund was established in Poland in 1992 (the First Polish American Trust Fund Pioneer), and another one only three years later. From 20 funds in 1997, the number of funds in 2004 increased more than seven times. The development of the investment funds market was influenced by further legal regulations and an increase in investment awareness of Poles.

The Act on Trust Funds of August 28, 1997 changed the nomenclature of funds (the trust fund was changed into an open-end investment fund) and gave the fund legal personality. In 1999, the first closed fund was created. The amendment of the Act in 2000 enabled the sale of fund units outside brokerage houses and through individuals. In this year, funds were created that invest outside of Poland and global funds (investing in Poland and abroad). In 2001, the bond and money market markets developed.

The entry into force of the Act on investment funds in 2004 had a major impact on the current shape of the investment fund market. The adaptation of Polish law to the regulations in force in the European Union unified the principles of fund management, information obligations of open funds and the rules for selling shares by foreign funds based in the EU. In 2004, the Management Board of Funds and Assets was also set up to carry out activities related to the operation of the funds and the standards of their operation.

At the end of 2004, the net assets of investment funds amounted to 37.43 (PLN bn), and at the end of December, the net asset value of the share-based funds alone was 29.63 (PLN bn).

Comparing the Polish and European Fund Markets, the share of fund assets registered in Poland in European Fund assets is small (around 0.5\%). Assets of funds are constantly growing, their share in relation to GDP increases, and the structure of the market from the point of view of their division into shares, bonds, money market, etc. reflects the structure of the European market [45].

One of the classification of funds is the division behind the Chamber of Fund and Asset Management, which lists the following types [30, 31, 32]: absolute return funds, equity funds, private equity funds, debt funds, cash and cash funds, mixed funds, real estate, capital protection, raw material market and securitization. In this structure, equity funds are in fourth place, having approximately $11-12 \%$ share in the investment fund market. This percentage gives net asset value at the level of 
PLN 33.17 billion as at the end of December 2017, even with a negative balance of sales (Table 1). A similar share of equity funds in the entire market does not mean that the net asset value remains unchanged. On the contrary, this value is gradually growing, except during the financial crisis, and the development of other types of funds gives a stable position of equity funds against the market.

Table 1

Net asset value of particular types of funds (as at the end of December 20017 and 2016)

\begin{tabular}{|l|c|c|}
\hline $\begin{array}{l}\text { Net asset value of individual types } \\
\text { of funds (PLN million) }\end{array}$ & December 2016 & December 2017 \\
\hline absolute return funds & 14999 & 15060 \\
\hline equity funds & 28234 & 33166 \\
\hline non-public asset funds & 103628 & 100597 \\
\hline debt funds & 43487 & 47566 \\
\hline cash and cash funds & 32185 & 41186 \\
\hline mixed funds & 24651 & 32544 \\
\hline real estate funds & 2265 & 2418 \\
\hline capital protection funds & 2442 & no data \\
\hline raw materials market funds & 1082 & 1060 \\
\hline securitization funds & 5951 & 5382 \\
\hline together & 258922 & 278979 \\
\hline
\end{tabular}

Source: own study

\section{Analyzed Fund Characteristics}

The subject of the research was 15 equity funds operating in Poland since 2003. 13 of them belong to Universal Funds, while 2 are funds investing in shares of small and medium-sized companies (Investor Top 25 Malych Spółek, Rockbridge Akcji Dynamiczne Spółek).

Table 2 lists the names of the funds covered by the study and the Company that manages them.

Table 2

Funds accepted for the study

\begin{tabular}{|r|l|l|c|}
\hline LP & \multicolumn{1}{|c|}{ Name of the fund } & \multicolumn{1}{|c|}{ TFI } & Sign \\
\hline 1 & $\begin{array}{l}\text { Arka BZ WBK Akcji } \\
\text { Polskich }\end{array}$ & $\begin{array}{l}\text { BZ WBK Towarzystwo Funduszy } \\
\text { Inwestycyjnych S.A. }\end{array}$ & Arka \\
\hline 2 & $\begin{array}{l}\text { Aviva Investors } \\
\text { Polskich Akcji }\end{array}$ & $\begin{array}{l}\text { Aviva Investors Poland Towarzystwo } \\
\text { Funduszy Inwestycyjnych S.A. }\end{array}$ & Aviva \\
\hline 3 & Esaliens Akcji & $\begin{array}{l}\text { Esaliens Towarzystwo Funduszy } \\
\text { Inwestycyjnych S.A. (dawniej Legg } \\
\text { Mason TFI S.A.) }\end{array}$ & Esaliens \\
\hline
\end{tabular}




\begin{tabular}{|r|l|l|c|}
\hline 4 & Investor Akcji & $\begin{array}{l}\text { Investors Towarzystwo Funduszy } \\
\text { Inwestycyjnych S.A. }\end{array}$ & Investor1 \\
\hline 5 & $\begin{array}{l}\text { Investor Akcji Spółek } \\
\text { Dywidendowych }\end{array}$ & $\begin{array}{l}\text { Investors Towarzystwo Funduszy } \\
\text { Inwestycyjnych S.A. }\end{array}$ & Investor2 \\
\hline 6 & $\begin{array}{l}\text { Investor Top 25 } \\
\text { Małych Spółek }\end{array}$ & $\begin{array}{l}\text { Investors Towarzystwo Funduszy } \\
\text { Inwestycyjnych S.A. }\end{array}$ & InvestorT \\
\hline 7 & Millennium Akcji & $\begin{array}{l}\text { Millennium Towarzystwo Funduszy } \\
\text { Inwestycyjnych S.A. }\end{array}$ & Millennium \\
\hline 8 & NN Akcji & $\begin{array}{l}\text { NN Investment Partners Towarzystwo } \\
\text { Funduszy Inwestycyjnych S.A. }\end{array}$ & NN \\
\hline 10 & Pioneer Akcji Polskich & $\begin{array}{l}\text { Pioneer Pekao Towarzystwo Funduszy } \\
\text { Inwestycyjnych S.A. }\end{array}$ & Pioneer \\
\hline 11 & PZU Akcji Krakowiak & $\begin{array}{l}\text { Towarzystwo Funduszy } \\
\text { Inwestycyjnych PZU S.A. }\end{array}$ & PZU \\
\hline 12 & Rockbridge Akcji & $\begin{array}{l}\text { Rockbridge Towarzystwo Funduszy } \\
\text { Inwestycyjnych S.A. }\end{array}$ & Rockbridge1 \\
\hline 13 & $\begin{array}{l}\text { Rockbridge Akcji } \\
\text { Dynamicznych Spółek }\end{array}$ & $\begin{array}{l}\text { Rockbridge Towarzystwo Funduszy } \\
\text { Inwestycyjnych S.A. }\end{array}$ & Rockbridge2 \\
\hline 14 & Skarbiec Akcja & $\begin{array}{l}\text { Skarbiec Towarzystwo Funduszy } \\
\text { Inwestycyjnych S.A. }\end{array}$ & Skarbiec \\
\hline 15 & UniKorona Akcje & $\begin{array}{l}\text { Union Investment Towarzystwo } \\
\text { Funduszy Inwestycyjnych S.A. }\end{array}$ & UniKorona \\
\hline
\end{tabular}

When analyzing funds in terms of net assets (Figure 1), one can notice a large difference in value. The funds with the largest market shares can be: NN Akcji, Arka BZW BK Akcji Polskich, Esaliens Akcji, Aviva Investors Polskich Akcji or PZU Akcji Krakowiak. The lowest net asset value is represented by Novo Akcji, Rockbridge Akcji Dynamicznych Spółek, Rockbridge Akcji and Investor Akcji Spółek Dywidendowych, which have a nearly nine times smaller share of net assets than the largest funds.

The type of fund, in accordance with the Act on investment funds of May 27, 2004, already imposes certain restrictions on the manner of investing. In addition, the funds in their prospectuses specify this in more detail, giving the upper or lower percentage of investing funds in shares. As of June 2017, it is shown in Figure 2. 


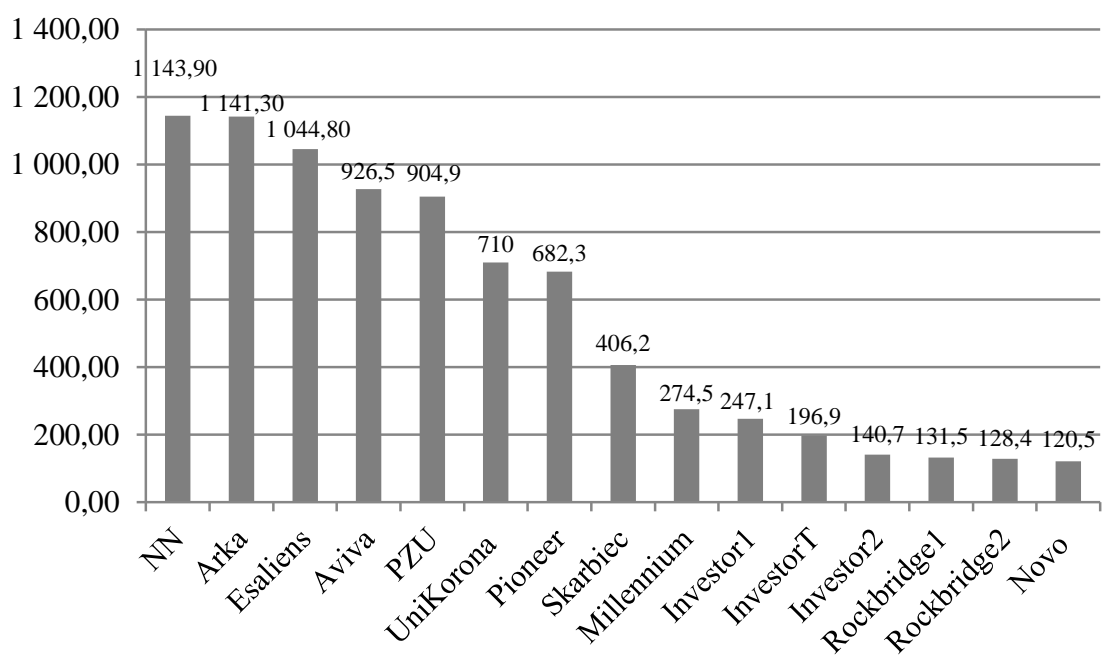

Figure 1

Net asset value in PLN million (as of January 2018)

Source: own study

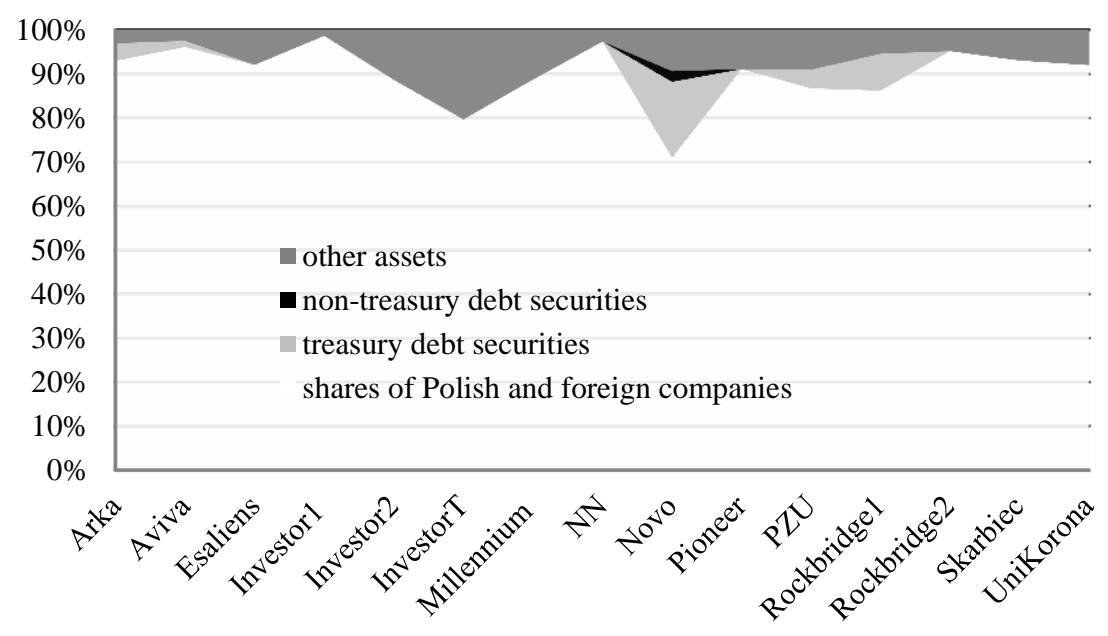

Figure 2

Asset Class (as at June 2017)

Source: own study 
Funds from $70.94 \%$ (in the case of the Novo Akcji fund) to $98.64 \%$ (in the case of the Investor Akcji fund) invest their assets in shares. Only five funds (Novo Akcji, Rockbridge Akcji, Pzu Akcji Krakowiak, Arka BZ WBK Akcji Polskich, Aviva Investors Polskich Akcji) had debt securities in their portfolios. They constituted from $1.41 \%$ in the case of Aviva Investors Polskich Akcji up to $17.2 \%$ for Novo Akcji. The Novo Akcji fund was the only one that held debt securities in its portfolio. The last component of the portfolio was other assets, i.e. deposits, derivatives, currencies and cash. Their share ranged from $1.36 \%$ to $11.35 \%$.

Focusing on the shares that accounted for the largest share in the portfolio, it can be seen that large funds invested primarily a significant part of their equity assets in large companies included in the WIG20 index (Figure 3). The share for the Arka BZW BK Akcji Polskich fund was 52.11\%. A small share in the portfolio of companies included in the WIG20 occurred, which is understandable, for the Rockbridge Akcji Dynamicznych Spólek (1.82\%) and Investor Top 25 Małych Spółek $(1.15 \%)$ funds. However, the situation was similar in the case of the Investor Akcji fund (companies from WIG20 constituted only $3.16 \%$ of the share assets). In addition to investing in large companies, the fund portfolio also includes medium-sized companies (from $9.41 \%$ to $39.99 \%$ ) and small (from $4.34 \%$ to $24.91 \%$ ). In addition, the portfolios of funds consist of shares that are not part of the listed indices. The share of such assets in the portfolio is from $12.47 \%$ to $58.57 \%$ in the case of the Investor Akcji fund.

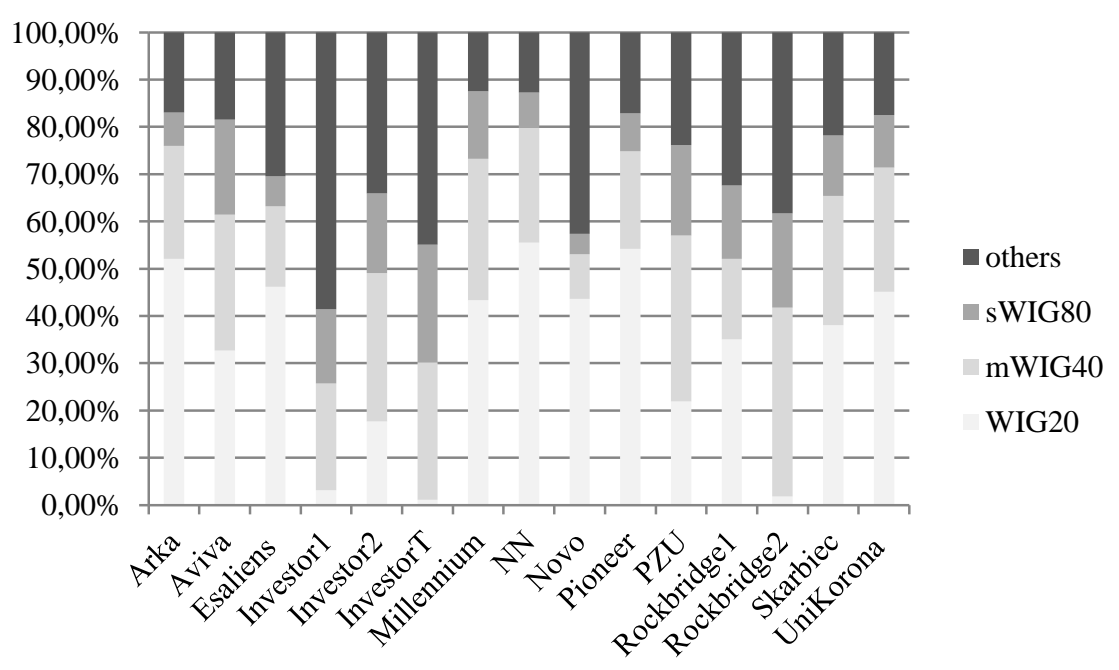

Figure 3

Structure of assets (as at June 2017) 


\section{Description and Methodology of the Test}

The presented analysis consisted of two stages. The first was an assessment of the interaction between changes in the valuation of fund units and changes in the quotations of the four main WSE indices in Warsaw: WIG, WIG20, mWIG40 and sWIG80. The causality test in the Granger sense was used for this purpose. In the second stage, the funds were classified taking into account the results of the causality test and portfolio structure.

Granger causality is defined in following way [16] [7]:

$$
\text { If } \operatorname{MSE}\left(\breve{Y}_{\mathrm{t}} \mid \mathrm{U}_{\mathrm{t}-1}\right)<\operatorname{MSE}\left(\breve{\mathrm{Y}}_{\mathrm{t}} \mid \mathrm{U}_{\mathrm{t}-1} \backslash \mathrm{X}_{\mathrm{t}-1}\right) \text { then to } \mathrm{X} \rightarrow \mathrm{Y}
$$

where: $U_{t-1}-$ set of previous information that is available at the moment $t, X_{t}-$ set of previous information that is available at the moment $t, X_{t}$ is a subset of $U_{t}$ : $X_{t} \subset U_{t}, Y_{t}$ - present value of the variable $Y\left(Y_{t} \subset U_{t}\right), \breve{Y}_{t}-$ unbiased forecast of variable $Y, M S E$ - mean square error of ex post forecast.

In other words, we can have interpreted it that changes of variable $X$,cause” the changes of variable $Y$ when we can better predict $Y$ using $X$. Such situation we mark it further as $X \rightarrow Y$, where arrow points to the direction of causality. The reverse relation is defined in an analogous way $Y \rightarrow X$.

When both relations occur simultaneously, i.e. $X \rightarrow Y$ and $Y \rightarrow X$, feedback or mutual causality is referred to and denotes as: $X \leftrightarrow Y$.

The parameters of the two models are estimated in the first step. First is the unrestricted model in the form:

$y_{t}=\alpha_{0}+\sum_{i=1}^{p} \alpha_{i} y_{t-i}+\sum_{i=1}^{q} \beta_{j} x_{t-j}+\varepsilon_{t}$

and the second, restricted model (with assumption that parameters $\beta_{j}$ are equal zero) is as follows:

$y_{t}=\alpha_{0}+\sum_{i=1}^{p} \alpha_{i} y_{t-i}+\varepsilon_{t}$

where: $x_{t^{-}}$value of variable $X$ in period $t ; y_{t}$ - value of variable $Y$ in period $t ; \alpha_{0}, \alpha_{i}$, $\beta_{\mathrm{j}}$ - parameters of the regressions.

The presented version of the test concerns stationary time series, therefore the rate of return of the analyzed series is used in the study:

$y_{t}=\ln \frac{Y_{t}}{Y_{t-1}}$ and $x_{t}=\ln \frac{X_{t}}{X_{t-1}}$

In the causal relationship $\mathrm{WIG} \rightarrow$ FIO for the variable $Y_{t}$, we accept the valuation of one investment fund and the variable $X_{t}$ for the quotation of one of the indices. 
On the other hand, for the FIO $\rightarrow$ WIG relationship, the variable $Y_{t}$ accepts the quotations of one of the indices and for the variable $X_{t}$, the valuation of one investment fund.

The set of hypotheses is formulated in this test as follows:

$\mathrm{H}_{0}: \beta_{j}=0$ for $j=1,2, \ldots, q$, changes in the $X$ process do not cause changes in the $Y$ process (short indication: $\neg X \rightarrow Y$ )

$\mathrm{H}_{1}: \beta_{j} \neq 0$ for $j=1,2, \ldots, q$, changes in the $X$ process cause changes in the $Y$ process $(X \rightarrow Y)$

When we have a large number of observation the test statistics is as follows (see [28], p. 177-178):

$W_{G}=\frac{R R S S-U R S S}{U R S S} \cdot T$

where: URSS - residual sum of squares from the unrestricted equation (1); RRSS residual sum of squares from the restricted equation (2).

The causality test is carried out for a different number of $p$ lags from 1 to 10 , with the assumption that the maximum delay of the variables $x_{t}$ and $y_{t}: p$ and $q$ are equal $(p=q)$. The rejection of the null hypothesis for a major numbers of lags will be interpreted as a situation where the changes in the quotation of one asset $(X)$ contribute more to changes in the quotation of the second asset $(Y)$, which in short we will consider as a stronger "causality effect", stronger reaction of the $Y$ processes for changes in the $X$ processes.

For the clustering was applied $k$-means method [29] [15]) and STATISTICA software. In turn, the procedure for conducting cluster analysis were taken from the work of [40]. Data was standardized and as a distance measure it was applied Euclidean distance. The $k$-means method is one of the most widely applied methods for data clustering. It consists of dividing the analyzed sample of objects into predefined number of cluster. This method consists in dividing the analyzed group of objects into predefined number of classes. In the first phase of analysis, objects (states) were divided into different number of clusters: groups: from 2 to $12(k=2,3, \ldots, 7)$. Then, based on silhouette index (SI, see [23]), the best divisions were selected. Walesiak reports that values over 0.5 designated that reasonable structure has been found. then the number of clusters is acceptable.

Diagnostic variables:

$Z_{1 i}$ - the number of rejections $\mathrm{H}_{0}$ in the Granger causality test, when the FIO $\rightarrow$ WIG relationship is tested (in the case of the $i^{\text {th }}$ fund);

$Z_{2 i}$ - the number of rejections $\mathrm{H}_{0}$ in the Granger causality test, when the FIO $\rightarrow$ WIG20 relationship is tested (in the case of the $i^{\text {th }}$ fund);

$Z_{3 i}$ - the number of rejections $\mathrm{H}_{0}$ in the Granger causality test, when the FIO $\rightarrow$ mWIG40 relationship is tested (in the case of the $i^{\text {th }}$ fund); 
$Z_{4 i}$ - the number of rejections $\mathrm{H}_{0}$ in the Granger causality test, when the FIO $\rightarrow$ sWIG80 relationship is tested (in the case of the $i^{\text {th }}$ fund);

$Z_{5 i}$ - share in the portfolio of $i^{\text {th }}$ fund of securities other than companies listed on the WSE;

$Z_{6 i}$ - share in the portfolio of the $i^{\text {th }}$ fund of companies listed in the WIG20 index;

$Z_{7 i}$ - share in the portfolio of the $i^{\text {th }}$ fund of companies listed in the mWIG40 index;

$Z_{8 i}$ - share in the portfolio of the $i^{\text {th }}$ equity fund companies in the sWIG80 index;

$Z_{9 i}$ - share in the portfolio of the $i^{\text {th }}$ fund of companies listed on the GPG but not included in the WIG20 or mWIG40 or sWIG80 indexes.

$Z_{1 i}-Z_{4 i}$ variables can have values from 0 to 10 , and $Z_{5 i}-Z_{9 i}$ variables from $0 \%$ to $100 \%$. To simplify the analysis, we adopted the composition of the portfolio for June 2017.

\section{Results}

The results of the Granger causality test (see Table 3 ) indicate that the changes in the values of the stock exchange indices cause changes in the valuation of investment fund units. What is the expected fact? Because, as mentioned earlier, the valuation of the fund depends, among other things, on the value of the assets included in the investment portfolio of the fund. On the other hand, the analyzed portfolios include companies that are listed within stock indices to a great extent. In addition, attention should be paid to the fact that the valuation of units is also affected by the interest in their purchase or sale, and this largely depends on the situation on the stock exchange. In other words, the bull market on the stock exchange contributes to an increase in interest in the investing in the FIOs and the bear market will cause a decrease in such interest.

Table 3

Results of the Granger causality test: lags $(p)$ for which $\mathrm{H}_{0}$ is rejected at the significance level of 0.05

\begin{tabular}{|c|c|c|c|c|c|c|c|c|}
\hline & 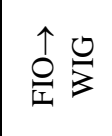 & $\underset{3}{\stackrel{0}{3}} \frac{0}{\uparrow}$ & 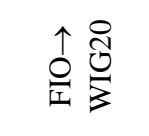 & 잉 & 个良 & 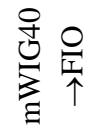 & $\begin{array}{l}\uparrow \\
\substack{\infty \\
0} \\
0\end{array}$ & $\sum_{\substack{\infty \\
0}}^{\infty} \frac{0}{\uparrow}$ \\
\hline Arka & $9 ; 10$ & $1-10$ & $5-10$ & $1-10$ & & $1-10$ & $2 ; 5$ & $1-10$ \\
\hline Inwestor1 & $3-5 ; 7-9$ & $1-10$ & $1-9$ & $1-10$ & & $1-10$ & $1-4 ; 8-10$ & $1-10$ \\
\hline $\mathrm{NN}$ & $3 ; 4$ & $1-10$ & $3-10$ & $1-10$ & & $1-10$ & $1-3 ; 5-7$ & $1-10$ \\
\hline Novo & & $1-10$ & 9 & $1-10$ & $1-4$ & $1-10$ & $1-10$ & $1-10$ \\
\hline PZU & $1 ; 3 ; 4 ; 6$ & $1-10$ & $1-10$ & $1-10$ & $4 ; 6-8$ & $1-10$ & $6 ; 10$ & $1-10$ \\
\hline Skarbiec & 4 & $1-10$ & $2 ; 4 ; 6 ; 8-10$ & $1-10$ & $5 ; 7 ; 8$ & $1-10$ & $1 ; 2 ; 6 ; 8$ & $1-10$ \\
\hline
\end{tabular}




\begin{tabular}{|l|l|l|l|l|l|l|l|l|} 
UniKorona & & $1-10$ & $3 ; 5 ; 6 ; 8-10$ & $1-10$ & $1-4 ; 10$ & $1-10$ & $1-10$ & $1-10$ \\
\hline Aviva & $2 ; 5-10$ & $1-10$ & $2-10$ & $1-10$ & & $1-10$ & & $1-10$ \\
\hline InvestorT & $2-10$ & $1-10$ & $1-10$ & $1-10$ & $2 ; 6 ; 7$ & $1-10$ & $1-3 ; 5 ; 10$ & $1-10$ \\
\hline Esaliens & $3 ; 5-10$ & $1-10$ & $2-10$ & $1-10$ & $3-8$ & $1-10$ & $4 ; 9 ; 10$ & $1-10$ \\
\hline Inwestor2 & & $1-10$ & $1-10$ & $1-10$ & & $1-10$ & $1 ; 2 ; 5-8$ & $1-10$ \\
\hline Millenium & $2 ; 5-8$ & $1-10$ & $1-10$ & $1-10$ & $1 ; 3 ; 4$ & $1-10$ & $4 ; 6$ & $1-10$ \\
\hline Rockbridge1 & $3 ; 8 ; 10$ & $1-10$ & $1-3 ; 6 ; 8 ; 10$ & $1-10$ & 3 & $1-10$ & $2 ; 3 ; 6 ; 7$ & $1-10$ \\
\hline Rockbridge2 & $1-9$ & $1-7$ & $1-4 ; 8$ & $1 ; 5-8$ & $2 ; 5$ & $1-10$ & & $1-10$ \\
\hline Pioneer & $2-10$ & $1-10$ & $1-10$ & $1-10$ & $1 ; 4-6$ & $1-10$ & $5 ; 6$ & $1-10$ \\
\hline
\end{tabular}

The Index $\rightarrow$ FIO designation indicates the results of the causality test where the changes in the index prices were the reason (in the Granger sense) of changes in the valuation of FIOs.

The FIO $\rightarrow$ Index designation indicates the results of the causality test where changes in the valuation of FIOs were the cause (in the Granger sense) of changes in the index prices.

The presented results indicate that changes in the values of the analyzed funds units may also be the cause (in the Granger sense) for changes in the index prices. The maximum number of rejections $\mathrm{H}_{0}$ (10 times) is obtained for three funds: Pioneer, InvestorT and Rockbridge2, and for two others (Millenium and Aviva) 9 rejections in the case of the FIO impact on the WIG index., The results indicate a significant stronger impact of changes in the value of FIO units on WIG20 index quotations in comparison to the other indices. There are at least $9 \mathrm{H}_{0}$ rejections for 13 funds out of 15 (9 rejections for Investor1, Arka, NN, Skarbiec, Millenium, Inwestor2 and Rockbridge 2 and 10 rejections for Esaliens, Pioneer, PZU, Aviva, InvestorT and Rockbridge2). UniKorona and Novo are funds for which we diagnose with a lack of causality with respect to the mWIG40 and sWIG80 indexes which at least $9 \mathrm{H}_{0}$ rejections. Interestingly, in the case of these funds, we have at most two $\mathrm{H}_{0}$ rejections in the FIO $\rightarrow$ WIG20 relationship and no $\mathrm{H}_{0}$ rejections in the FIO $\rightarrow$ WIG relationship. UniKorona and Novo are the only funds which do not affect changes in the WIG index.

It is worth noting that for the major FIOs ( 8 out of 15) the rejection of the null hypothesis $\neg$ FIO $\rightarrow$ WIG20 takes place already for the first lag $(p=1)$ in the case of the WIG20 index. They are mainly funds with small capitalization, less than 300 million PLN (Millenium, InvestorT Inwestor1, Inwestor2, Rockbridge1, Rockbridge2). The other two (PZU and Pioneer) can be defined as medium-sized funds (with the portfolio value above 600 million PLN, but not exceeding 1000 million PLN). However, it should be noted that the shares of managing authorities of these portfolios (PZU and PEKAO SA) constitute a significant share in the composition of the WIG20 index. In turn, for the three largest funds (with the portfolio value above 1000 million PLN) the impact of the FIO valuation on the index quotation is visible only after at least two periods. This phenomenon is explained by the fact that money management in the smaller funds is more flexible (i.e. it is easier to withdraw them from the market) than in the case of large funds. 
On the other hand, in the case of PZU and Pioneer funds, we expect that their valuation is strongly related to the valuation of shares in the managing institutions of these funds. In turn, they have a large share in the WIG20 index, therefore the companies price of these institutions is closely related to the WIG20 index. Such an interpretation may be a research hypothesis for the next study.

The last stage of the analysis is funds clustering applying the $k$-means method. The results are presented in the Table 4 . The best division is found in 5 groups. The values of the silhouette index in this case is 0.768 , which indicates a very good division (with the so-called strong class structure). We obtain three oneobject clusters (Unikorona in group 1, Investor1 in group 2 and Novo in group 4). Two clusters include six funds each of them. There are such funds as Arka, NN, Skarbiec, Esaliens, Millenium and Pioneer in group 3. This group is characterized by a significant number of $\mathrm{H}_{0}$ rejections in the FIO $\rightarrow$ WIG20 relation (about 9 rejections on average) and in the FIO $\rightarrow$ WIG relation (about 7 rejections on average). On the other hand, in the FIO $\rightarrow$ mWIG40 relation we notice a low number of rejections (the average is 0.3 ). $\mathrm{H}_{0}$ is rejected 3 times on average in the FIO $\rightarrow$ sWIG80 relation. This group was characterized by a fairly high share of WIG20 companies (48.3\% on average) and a relatively low share of companies not listed in the main WSE indices (18.6\% on average) in comparison to other clusters. Group 5 includes following funds: PZU, Aviva, InvestorT, Inwestor2, Rockbridge1, Rockbridge2. In this group, we observe a significant number of $\mathrm{H}_{0}$ rejections in the FIO $\rightarrow$ WIG and FIO $\rightarrow$ WIG20 relations (7.2 and 9.7 on average respectively).

Table 4

Group average

\begin{tabular}{|c|c|c|c|c|c|c|c|c|c|c|}
\hline FIO in a group & 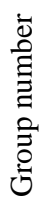 & 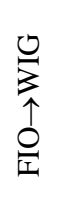 & 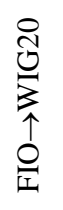 & 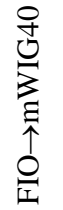 & $\begin{array}{l}0 \\
0 \\
0 \\
\sum_{\infty} \\
1 \\
0 \\
0\end{array}$ & 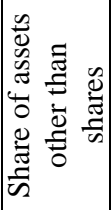 & 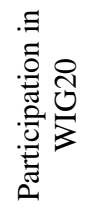 & 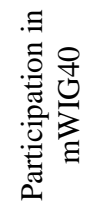 & 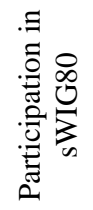 & 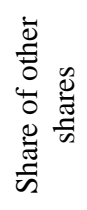 \\
\hline UniKorona & 1 & 0 & 1 & 9 & 10 & $8.0 \%$ & $45.2 \%$ & $26.2 \%$ & $11.2 \%$ & $17.5 \%$ \\
\hline Inwestor1 & 2 & 2 & 9 & 0 & 7 & $1.4 \%$ & $3.2 \%$ & $22.5 \%$ & $15.7 \%$ & $58.6 \%$ \\
\hline $\begin{array}{l}\text { Arka, NN } \\
\text { Skarbiec, } \\
\text { Esaliens, } \\
\text { Millenium, } \\
\text { Pioneer }\end{array}$ & 3 & 7 & 9.3 & 0.3 & 2.7 & $7.6 \%$ & $48.3 \%$ & $23.9 \%$ & $9.3 \%$ & $18.6 \%$ \\
\hline Novo & 4 & 0 & 2 & 10 & 10 & $29.1 \%$ & $43.6 \%$ & $9.4 \%$ & $4.3 \%$ & $42.6 \%$ \\
\hline $\begin{array}{l}\text { PZU, Aviva, } \\
\text { InvestorT, } \\
\text { Inwestor2 } \\
\text { Rockbridge1, } \\
\text { Rockbridge2 }\end{array}$ & 5 & 7.2 & 9.7 & 1.3 & 1.3 & $12.9 \%$ & $18.4 \%$ & $30.3 \%$ & $19.4 \%$ & $32.0 \%$ \\
\hline
\end{tabular}




\section{Conclusions}

The presented results indicate that Fund Groups significantly differentiate more because of the structure of the Fund's portfolios, than the relationships and the interactions with the main stock exchange indices. The vast majority of Funds in relation to WIG and WIG20 indexes are characterized by causality, which can be described as bilateral (Index $\leftrightarrow$ FIO). The influence of the changes in the values of the stock exchange indices on the valuation of investment fund (Index $\rightarrow$ FIO) units is evident. Primarily, because of the fact that the valuation of the Fund depends on the value of the assets included in the investment portfolio of the Fund, among other things. In turn, we also diagnosed the reverse relation $(\mathrm{FIO} \rightarrow$ Index $)$. Such situations can be explained by several factors, i.e.: immediate impact, institutional herding or long-term trends. It is almost worthless, that the analyzed FIO's portfolios include companies that are listed within stock indices, to a great extent and cannot remain inconsequential. On the other hand, the FIO relationship with the mWIG40 and sWIG80 indexes can be described as, onesided (Index $\rightarrow$ FIO). While changes in index prices affect changes in the valuation of Funds, the reverse relation is observed to a limited extent. Such situations can be explained by the policies pursued by the Funds. They adjust to the whole market (stock exchange) trends as described by major indices, in our analysis, they are WIG and WIG20.

\section{References}

[1] Alexakis C., Niarchos N., Patra T., Poshakwale S.: The dynamics between stock returns and mutual fund flows: Empirical evidence from the Greek market. International Review of Financial Analysis, Vol. 14(5) 2005, pp. 559-569, https://doi.org/10.1016/j.irfa.2004.10.019

[2] Aydoğan B., Vardar G., Tunç G.: The Interaction of Mutual Fund Flows and Stock Returns: Evidence From The Turkish Capital Market. Ege Academic Review, 14(2) 2014, pp. 163-173

[3] Bailey W., Choi J. J.: International market linkages, Journal of Economics and Business, Vol. 55, 2005, pp. 399-404

[4] Boyte-White C.: How Mutual Funds Affect Stock Prices, Inwestopedia 2015, https://www.investopedia.com/articles/investing/, d.d.22.05.2018

[5] Burucu H., Contuk F. Y.: The dynamics between mutual funds flows and stock returns: empirical evidence from the turkey markets, International Journal of Economics and Finance Studies, Vol. 3(1) 2011, pp. 95-109

[6] Cao C., Chang E. C., Wang Y.: An empirical analysis of the dynamic relationship between mutual fund flow and market return volatility, Journal of Banking \& Finance, Vol. 32(10) 2008, pp. 2111-2123, https://doi.org/10.1016/j.jbankfin.2007.12.035

[7] Charemza W. W., Deadman D. F.: New Directions In Econometric Practice, Second Edition, Books, Edward Elgar Publishing, number 1139, April 1997 
[8] Deutsche Bundesbank. Monthly Report January 2013, Current developments in the mutual funds market: demand, structural changes and investor behavior

[9] Edwards F., Zhang X.: Mutual Funds and Stock and Bond Market Stability, Jolcrrznl of Finnilcia1 Services Resenrch, 13, 1998, pp. 257-282

[10] Enders W.: Applied econometric time series, John Wiley \& Sons, 2008

[11] Engle R., Granger C.: Long Run Economic Readings in Cointegration, Oxford University Press, New York 1991

[12] Engle R. F., Granger C. W. J.: Cointegration and error correction mechanism: Representation, Estimation and Testing, Econometrica, 55, 1987, pp. 251-276

[13] Francis B. B., Leachman L. L.: Superexogeneity and the dynamic linkages among international equity markets, Journal of International Money and Finance, Vol. 17, 1998, pp. 475-492

[14] Frey S., Herbst P., Walter A.: Measuring Mutual Fund Herding: A Structural Approach, mimeo 2007

[15] Gatnar E., Walesiak M. (ed.): Metody statystycznej analizy wielowymiarowej w badaniach marketingowych, Wydawnictwo AE we Wrocławiu, Wrocław 2004

[16] Granger C. W. J.: Investigating Causal Relations by Econometric Models and Cross-spectral Methods, Econometrica, 37 (3) 1969, pp. 424-438, DOI: $10.2307 / 1912791$

[17] Granger C. W. J.: Some Properties of Time Series Data and Their Use in Econometric Model Specification, Journal of Econometrics 16, 1981, pp. $121-130$

[18] Hossain M. S., Rahman A. M., Rajib M. S. U.: Dynamics of Mutual Funds in Relation to Stock Market: A Vector Autoregressive Causality Analysis, International Journal of Economics and Financial Issues, Vol. 3(1), 2012, pp. 191-201

[19] Hsiehy M. F., Yangz T. Y., Yangx Y. T., Lee J. S.: Evidence of Herding and Positive Feedback Trading for Mutual Funds in Emerging Asian Countries, Quantitative Finance, 11(3) 2011, pp. 423-435, https://doi.org/10.1080/14697688.2010.506882

[20] Jank S.: Mutual fund flows, expected returns, and the real economy, Journal of Banking \& Finance, Vol. 36(11) 2012, pp. 3060-3070, https://doi.org/10.1016/j.jbankfin.2012.07.004

[21] Johansen S.: Estimation and hypothesis testing of cointegration vectors in Gaussian vector autoregressive models, Econometrica: Journal of the 
Econometric Society, Vol. 59(6) 1991, pp. 1551-1580, DOI: $10.2307 / 2938278$

[22] Kasa K.: Common stochastic trends in international stock markets, Journal of Monetary Economics, Vol. 29, 1992, pp. 95-124

[23] Kaufman L., Rousseeuw P. J.: Finding Groups in Data: an Introduction to Cluster Analysis, Wiley, New York 1990

[24] Kearney C., Lucey B. M.: International equity market integration: Theory, evidence and implications, International Review of Financial Analysis, Vol. 13, 2004, pp. 571-583

[25] Lakonishok J., Shleifer A., Vishny R.: The impact of institutional trading on stock pricing, Journal of Financial Economics 32, 1992, pp. 23-43

[26] Li H., Majerowska E.: Testing stock market linkages for Poland and Hungary: A multivariate GARCH approach, Research in International Business and Finance, Vol. 22, 2008, pp. 247-266

[27] Lobão J., Levi A.: The relation between mutual fund flows, stock returns and macroeconomic variables: evidence from Portugal, Portuguese Journal of Finance, Management and Accounting, Vol. 2(4) 2016, pp. 54-75

[28] Maddala G. S.: Introduction to econometrics (Vol. 2), New York: Macmillan, 1992

[29] McQueen J. B.: Some methods for classification and analysis of multivariate observations, Proceedings of $5^{\text {th }}$ Berkeley Symposium on Mathematical Statistics and Probability, University of California Press, Berkeley 1967

[30] Mentel G., Brożyna J., Szetela B.: Evaluation of the effectiveness of investment fund deposits in Poland in a time of crisis, Journal of International Studies, 10(2), 2017, pp. 46-60, DOI:10.14254/2071$8330.2017 / 10-2 / 3$

[31] Mentel G., Horváthová Z.: Factors of Efficiency of Open Investment Funds in 1997-2015, Economics and Sociology, Vol. 9, No. 1, 2016, pp. 101-113, DOI: $10.14254 / 2071-789 X .2016 / 9-1 / 7$

[32] Mentel G., Szetela B., Tvaronavičienė M.: Qualifications of Managers vs. Effectiveness of Investment Funds in Poland, Economics and Sociology, Vol. 9, No. 2, 2016, pp. 126-136, DOI: 10.14254/2071-789X.2016/9-2/8

[33] Naik P. K., Padhi P.: An Empirical Evidence of Dynamic Interaction between Institutional Fund Flows and Stock Market Returns in India, Indian Journal of Finance, Vol. 9(4) 2015, pp. 21-32, DOI: 10.17010/ijf/2015/v9i4/71455 
[34] Oha N. Y., Parwada J. T.: Relations between Mutual Funds Flows and Stock Market Returns in Korea, International Financial Markets, Institutions and Money, 17, 2007, pp. 140-151

[35] Pojanavatee S.: Cointegration and causality analysis of dynamic linkage between stock market and equity mutual funds in Australia, Cogent Economics \& Finance, Vol. 2(1) 2014), 918855 (on-line) https://doi.org/10.1080/23322039.2014.918855

[36] Potter M.: The dynamic relationship between security returns and mutual fund flows, University of Massachusetts-Amherst, PhD dissertation 1996

[37] Ramelona E., Kleiman P., Gruenstein D.: Market returns and mutual fund flows, FRBNY Economic Policy Review, 33-52, Federal Reserve Bank of New York 1997

[38] Satoła Ł.: Dynamika wartości aktywów na polskim rynku funduszy inwestycyjnych, Zeszyty Naukowe Polityki Europejskie, Finanse i Marketing, Nr 4 (53) 2010

[39] Syriopoulos T.: Dynamic linkages between emerging European and developed stock markets: Has the EMU any impact?, International Review of Financial Analysis, Vol. 16, 2007, pp. 41-60

[40] Walesiak M.: Rekomendacje w zakresie strategii postępowania w procesie klasyfikacji zbioru obiektów, in: A. Zeliaś (ed.), Przestrzenno-czasowe modelowanie zjawisk gospodarczych. Materiały z XXVII Ogólnopolskiego Seminarium Naukowego, Wydawnictwo AE w Krakowie, Kraków 2006, pp. $185-203$

[41] Walter A., Weber F. M.: Herding in the German Mutual Funds Industry, European Financial Management, 12(3) 2006, pp. 375-406, https://doi.org/10.1111/j.1354- 7798.2006.00325.x

[42] Warther V. A.: Aggregate mutual fund flows and security returns, Journal of Financial Economics, 39, 1995, pp. 209-235

[43] Wermers R.: Mutual fund herding and the impact on stock prices, Journal of Finance 54, 1999, pp. 581-622

[44] Yangbo B., Wickramanayake J., Watson J., Tsigos S.: The relationship between mutual fund flows and stock market returns: a comparative empirical analysis, Corporate Ownership \& Control, Volume 8(1) 2010, pp. 785-799, http://dx.doi.org/10.22495/cocv8i1c8p4

[45] Żebrowska-Suchodolska D., Karpio A.: Polski rynek otwartych funduszy inwestycyjnych na tle rynku europejskiego, Zeszyty Naukowe SGGW w Warszawie Scientific Journals Nr 4(53) 2010, Polityki Europejskie, Finanse i Marketing Nr 4(53) 2010, pp. 322-331 